\title{
Developing the Set of Mathematics Learning Materials Based on NHT Model With Peer Assessment
}

\author{
Asri Fauzi* \\ Elementary School Teacher Education Study Program \\ Universitas Mataram \\ Mataram, Indonesia \\ asrifauzi@unram.ac.id \\ Djamilah Bondan Widjajanti \\ Mathematics Education Study Program \\ Universitas Negeri Yogyakarta \\ Yogyakarta, Indonesia
}

\author{
Arif Widodo \\ Elementary School Teacher Education Study Program \\ Universitas Mataram \\ Mataram, Indonesia \\ Umar Umar \\ Elementary School Teacher Education Study Program \\ Universitas Mataram \\ Mataram, Indonesia
}

\begin{abstract}
This study aims at developing a valid, practice and effective set of mathematics learning materials based on Numbered Heads Together (NHT) model with peer-assessment to enhance students' conceptual understanding and achievement. To fulfil the goal, the research was carried in research development setting using ADDIE model (Analysis, Design, Development, Implementation, Evaluation). There are two products in the set of learning materials, which are lesson plans and student's worksheets. To ensure the data validity, the developed products were validated by two experts. Afterwards, the revised products were implemented in a junior high school in Selong, Nusa Tenggara Barat-Indonesia, with 1 mathematics teacher and 32 students, to evaluate its practicality and the effectiveness. The data from teacher's and students' assessment sheets, students' work in test and classroom observation were collected during this implementation process. The data were analyzed by converting the total quantitative data scores obtained into five scale qualitative data. The results showed that the instructional package developed were valid, practical, and effective to improve both students' mathematics conceptual understanding and achievement.
\end{abstract}

Keywords - set of learning materials, NHT, peer assesment, conceptual understanding, learning outcome

\section{INTRODUCTION}

From years, the low achievement of students in learning mathematics become a highlight worldwide. No doubt, the researchers and educators attempted to solve the problem by looking at the core of the problem. It was found that there is significant relation between students' conceptual understanding and students' achievement in mathematics [1]. Therefore, to improve the students' achievement, their conceptual understanding should be secured.

By learning mathematics, the students are expected to implement their understanding to explore, investigate and solve problems creatively [2]\&[3]. Therefore, conceptual understanding considered as a crucial skill for students. The understanding in basic topic will enable students to learn more advance or complex mathematics as they start making connection among mathematical topics [4]. Also, learning by focusing on conceptual mastery will enhance the retention of the knowledge and facilitate the students to learn flexibly [5].
The students' conceptual understanding can be observed from their abilities to: (a) define a concept, both verbally and written, (b) make an example and nonexample, (c) represent a concept using models, diagrams or symbols, (d) convert a representation to other forms of representation, (e) able to interpret the concept, (f) identify the properties and requirements of concept, (g) compare and differentiate difference concepts [6]. In addition, students' conceptual understanding can also be seen from their ability in giving examples. It can also be seen from students' ability in classifying concepts and re-explaining what the concepts mean using their own words [7].

To improve the students' conceptual understanding, some researchers try to implement a student-centered learning in which the teacher plays crucial role to supports by providing meaningful feedback and situating the environment that enacting students to learn [8]\&[9]. However, some teachers afraid of not having enough time to response in all students' ideas since, often, the class size is too large and no adequate learning resources in school $[10] \&[11]$. Here, the use of cooperative learning will be beneficial.

One type of a powerful cooperative learning is Numbered Heads Together (NHT). NHT is a structured learning/working system in which the students' relationship in a group become positive interdependence [12]. Here, the students will develop individual responsibility, personal interaction and collaborative skills since the students spend majority of their learning in the classroom with their group's members. NHT enables the students to think and interact with their peers. This interaction enable them to strengthen their understanding and choose the best solution after hearing the other ideas from the group's member[13].

To enhance the quality of learning, the teacher should be aware with the assessment employed in a cooperative setting since it will influence the students' motivation and achievement [14]. Assessment should not be considered only as a final evaluation (summation test) to assign the scores for students, but also to reflect on the process of learning (formative test) [15]\&[16]. One type of formative assessment is assessment for learning (AfL) which emphasizes the process of gathering and making use the 
crucial information during learning to improve the quality of activities in the next meeting [17].

In cooperative learning setting, the formative assessment can be done by using peer assessment since everyone can provide and receive feedbacks from others [18]. Peer assessment is a qualitative or quantitative evaluation given to a student's performances, works or ideas provided by classmates or group members [19]. It aimed to develop students' reflection skills by collaboration work [20].

To promote the best result in the implementation of NHT with peer assessment, the teacher and students should be guided by a valid, practice and effective learning set materials. However, the lack of sources become a burden for the learning process. Therefore, this study aimed to develop the set of learning materials, including lesson plan for teacher, worksheet for students and test for students' conceptual understanding and achievement in mathematics.

\section{METHODS}

The presented study was Developmental Research to develop the set of learning materials, which are lesson plans and student's worksheets in mathematics. ADDIE model was employed with five stages of Analysis, Design, Development, Implementation and Evaluation.

The analysis stage was done by analyzing the needs of developing the learning materials based on NHT model with peer assessment. After that, in Design stage, the lesson plans and student's worksheets were developed after considering the results from needs assessment and literature review. The first prototype was examined in the Development stage in which the products were reviewed by peer assessment and validated by expert judges. The suggestions and remarks were used to revise the prototype. The second prototype followed the Implementation stage where the products were implemented in the real classroom to assess its practicality and effectiveness. The overall data were evaluated in Evaluation stage.

The data related to validity of the set of materials were gathered from experts' judgement. The data were analyzed quantitatively using descriptive method by comparing the empiric score $(X)$, ideal mean score $\left(\bar{X}_{l}\right)$ and the ideal standard deviation $\left(S D_{i}\right)$. The scores gained from the experts were converted into qualitative data in five categories [21] as in Table 1.

TABLE 1. SCORE CONVERSION IN FIVE QUALITATIVE SCALES

\begin{tabular}{|l|l|}
\hline Interval & Criteria \\
\hline$X>\bar{X}_{l}+1.8 S D i$ & Very Good \\
\hline $\bar{X}_{l}+0.6 S D i X<X \leq \bar{X}_{l}+1.8 S D i$ & Good \\
\hline $\bar{X}_{l}-0.6 S D i X<X \leq \bar{X}_{l}+0.6 S D i$ & Fair \\
\hline $\bar{X}_{l}-1.8 S D i X<X \leq \bar{X}_{l}-0.6 S D i$ & Poor \\
\hline$X \leq \bar{X}_{l}-1.8 S D i$ & Very Poor \\
\hline
\end{tabular}

The data related to practicality were gathered from students' and teacher's evaluation sheets given after the class conducted using the developed learning materials. It was analyzed using descriptive quantitative. The scores were converted using the same conversion in Table 1.
The effectiveness data were gained from students' written work in conceptual understanding and achievement tests. The data were analyzed using Proportion Z-test. The developed materials are considered effective to improve the students' conceptual understanding and achievement in mathematics if $75 \%$ of the students' scores were higher than the minimum requirement score for mathematics which is 70 .

\section{RESULTS AND DISCUSSION}

The lesson plans and student's worksheets developed in the study were based on the NHT cooperative learning model with the peer assessment. Therefore, the lessons followed the syntax of NHT, in which the teacher should: (1) distribute the students into small heterogenous groups (sexually and academically), each consists of 4-5 people, (2) label everyone in the group as 1 to 5, (3) announce the activity in front of the classroom, (4) distribute worksheet to the groups, (5) facilitate the students in a group discussion, make sure that everyone in the group discuss to choose the best answer for the given problem, (6) randomly call one of the number (1-5), everyone in the group that assigned to the particular number will present the discussion result and others will provide feedbacks, (8) after all groups presenting their discussion, provide essential problem to be independently solved in 10-15 minutes, (9) facilitate and guide students to cross-check their answer in solving the previous problem (in step 8) with their peers, (10) ask some students to present the feedback they got from the peers in front of the classroom, (11) collect the students' work to be evaluated further after class dismiss, (12) give homework for students and (13) encourage students to make conclusion related to the materials.

From the experts' judgement, it was found that the developed lesson plans and student's worksheets were valid and ready to use after some revision. The recapitulation of scores for each item provided in Table 2 .

TABLE 2. SCORE RECAPITULATION FOR VALIDITY OF LESSON PLANS AND STUDENT'S WORKSHEETS

\begin{tabular}{|l|l|l|}
\hline Developed Item & $\begin{array}{l}\text { Average Score from } \\
\text { Evaluation Sheets }\end{array}$ & Category \\
\hline Lesson Plan & 87 & Very Good \\
\hline Student's Worksheets & 92 & Good \\
\hline
\end{tabular}

Furthermore, the quality of product based on the practicality aspect were analyzed from teacher's and students' evaluation after the implementation of the lesson plans and worksheet in the teaching and learning process. The summary of the scores from each side (teacher and students) can be observed in the following Table 3 .

TABLE 3. SCORE RECAPITULATION FOR PRACTICALITY OF LESSON PLANS AND STUDENT'S WORKSHEETS

\begin{tabular}{|l|l|l|l|}
\hline $\begin{array}{l}\text { Evaluation } \\
\text { Score }\end{array}$ & $\begin{array}{l}\text { Average } \\
\text { Score }\end{array}$ & $\begin{array}{l}\text { Maximum } \\
\text { Score }\end{array}$ & Category \\
\hline From Teacher & 83 & 95 & $\begin{array}{l}\text { Very } \\
\text { Good }\end{array}$ \\
\hline From Student & 35,13 & 45 & Good \\
\hline
\end{tabular}

Based on the observation during the implementation of the developed materials, it was found that the average 
percentage of completion for teacher and students' activity were $93 \%$ and $88 \%$ respectively. Therefore, the developed lesson plans and student's worksheets were considered as practice to use in the classroom.

The effectivity of the developed materials was evaluated from students' scores in conceptual understanding test and standard achievement test in mathematics. Based on the conceptual understanding test, $94 \%$ of students' scores were higher than 70 , the minimum requirement for mathematics subject. From the normality test using One-Sample Kolmogorov-Smirnov test, it was found that the score for conceptual understanding was 0.078 which is greater than $\alpha=0.05$. It means the data were normally distributed. Therefore, the evaluation was continued by Proportion $Z$-test. From the test it was found $Z=2.449$ and it was greater than $Z_{\alpha}=1.645$ which means the proportion of students whose scores greater than the minimum requirement was more than $75 \%$. Hence, it can be concluded that the developed lesson plans and student's worksheets were effective to improve the students' conceptual understanding in mathematics.

Furthermore, according to achievement test, $91 \%$ of students' scores were higher than 70 , the minimum requirement for mathematics subject. The normality test using One-Sample Kolmogorov-Smirnov test revealed that the data were normally distributed since the score was 0.089 and it was greater than $\alpha=0.05$. The evaluation of the hypothesis was continued using Proportion Z-test. From the test it was found $Z=2.041$ and it was greater than $Z_{\alpha}=1.645$. Hence, there are more than $75 \%$ of students who pass the minimum score which is 70 . Therefore, it can be inferred that the developed lesson plans and student's worksheets were effective to improve the students' achievement in mathematics.

The developed learning materials based on NHT model with peer assessment effective to improve students' learning outcome since it encourages the students to actively engage in learning process. The step in which the students can be randomly selected to present the group discussion in front of the classroom enhance the students' awareness to be involved in the discussion. The students have to make sure they have sufficient understanding toward the group discussion as they have the same amount of responsibility to perform the best in the group. The type of personal and group responsibility in NHT model contributes to the students' improvement in cognitive learning outcome [13].

Also, the independent practice after the group presentation as the formative assessment in helps the students to evaluate their own learning result. According to Stiggins [17] the assessment for evaluation should be done continuously to present an authentic evidences of the students' mastery in the topics. The good evaluation will provide the chance for the students to perform their actual learning result based [15].

The peer assessment provide right after the independent practice leads the students to a deep reflection. This process was guided by the teacher, but each of the student should carefully assess their peer's works. Here, they have to understand the materials and determine whether their friends solve the problem correctly. From the process, the student also reflected on their method and strategy and developed further understanding. The peer assessment provides a great support for students' improvement in collaboration, communication, conceptual understanding and problem solving.

\section{CONCLUSION}

From the analysis of the results, it can be concluded that the developed set of learning materials based on NHT and peer assessment was in valid criteria, practice and effective to improve the students conceptual understanding and achievement in mathematics. Therefore, this study recommends the use of the developed lesson plans and student's worksheets in the classroom to enhance students' collaborative learning that will be beneficial for their learning experience. The further study also can be conducted to develop the peer assessment instrument will enable students to reflect on their own learning while provide feedback for their classmates.

\section{REFERENCES}

[1] E. Istikomah, "The relationship between conceptual understanding and student learning outcomes through the use of geometers Sketchpad software," J. Phys. Conf. Ser., vol. 1157, no. 4, pp. 9 13, 2019, doi: 10.1088/1742-6596/1157/4/042070.

[2] A. J. Makinster, Alan Crawford, E. Wendy Saul, Samuel Mathews, Teaching and learning strategies for the thinking classroom. New York: RWCT International Consortium, 2005.

[3] P. Phonapichat, S. Wongwanich, and S. Sujiva, "An Analysis of Elementary School Students' Difficulties in Mathematical Problem Solving," Procedia - Soc. Behav. Sci., vol. 116, no. 2012, pp. 3169-3174, 2014, doi: 10.1016/j.sbspro.2014.01.728.

[4] M. W. Douglas K. Brumbaugh, Peggy L. Moch, Mathematics Content For Elementary Teachers. London: Lawrence Erlbaum Associates, 2005.

[5] D. P. Newton, Teaching for Understanding: What It Is and How To Do It. London: Routledge.

[6] N. C. of T. of M. (NCTM), Principles and standards for school mathematics. Reston: NCTM Inc, 2000.

[7] S. Wardhani, Standar penilaian pendidikan (implikasinya terhadap tugas guru matematika dan sekolah). Yogyakarta: Pusat Pengembangan dan Pemberdayaan Pendidik dan Tenaga Kependidikan Matematika, 2010.

[8] I. N. Gita and R. A. Apsari, "Scaffolding in problem based learning to increase students' achievements in linear algebra," $J$. Phys. Conf. Ser., vol. 1040, no. 1, 2018, doi: 10.1088/17426596/1040/1/012024.

[9] S. F. H. S. Zain, F. E. M. Rasidi, and I. I. Z. Abidin, "StudentCentred Learning In Mathematics Constructivism In The Classroom," J. Int. Educ. Res., vol. 8, no. 4, pp. 319-328, 2012, doi: 10.19030/jier.v8i4.7277.

[10] S. Pedersen and M. Liu, "Teachers' beliefs about issues in the implementation of a student-centered learning environment," Educ. Technol. Res. Dev., vol. 51, no. 2, pp. 57-76, 2003, doi: 10.1007/BF02504526.

[11] K. Kari Jabbour, "Issues that restrain teachers from adapting student-centered instruction in lebanese school," Tejuelo Didáctica la Leng. y la Lit. Educ., vol. 17, no. 17, pp. 85-96, 2013.

[12] Anita Lie, Mempraktikan Cooperative Learning Di Ruang-Ruang Kelas. Jakarta: Grasindo, 2010.

[13] L. Marleny and C. Aloysius Duran, "The effect of numbered heads together (NHT) cooperative learning model on the cognitive achievement of students with different academic ability," J. Phys. Conf. Ser., no. 795, pp. 1-9, 2016, doi: 10.1088/17426596/755/1/011001.

[14] J. Lu and N. Law, "Online peer assessment: Effects of cognitive 
and affective feedback," Instr. Sci., no. 40, pp. 257-275, 2012, doi: 10.1007/s11251-011-9177-2.

[15] J. M. B.-W. John A. Van De Walle, Karen S. Karp, Elementary and Middle School Mathematics Teaching Developmentally (9th ed). United States: Person Education, 2016.

[16] Kemendikbud, Modul pengembangan instrument penilaian oleh pendidik mata pelajaran matematika sekolah menengah pertama. Jakarta: Kemendikbud, 2016.

[17] R. Stiggins and J. Chappuis, "Using student-involved classroom assessment to close achievement gaps," Theory Pract., vol. 44, no. 1, pp. 11-18, 2005, doi: 10.1207/s15430421tip4401_3.

[18] D. Reinholz, "The assessment cycle: a model for learning through peer assessment," Assess. Eval. High. Educ., pp. 1-115, 2016, doi: 10.1080/02602938.2015.1008982.

[19] K. J. Topping, "Peer assessment," Theory Pract., vol. 48, no. 1, pp. 20-27, 2009, doi: 10.1080/00405840802577569.

[20] A. Karami and A. Rezaei, "An Overview of Peer-Assessment: The Benefits and Importance," J. Study English Linguist., vol. 3, no. 1, pp. 93-100, 2015, doi: 10.5296/jsel.v3i1.7889.

[21] E. P. Widoyoko, Evaluasi Program Pembelajaran Panduan Praktis Bagi Pendidik Dan Calon Pendidik. Yogyakarta: Pustaka Pelajar, 2017. 